\section{OPEN ACCESS}

Edited by:

Joanna Wieronska,

Polish Academy of Sciences, Poland

Reviewed by:

Olivier Thibault,

University of Kentucky, United States

Agnieszka Basta-Kaim,

Polish Academy of Sciences, Poland

*Correspondence: Miroljub Popovic miroljub@um.es

Specialty section:

This article was submitted to

Neuropharmacology,

a section of the journa

Frontiers in Pharmacology

Received: 15 February 2020 Accepted: 14 April 2020

Published: 05 May 2020

Citation:

Popović N, Morales-Delgado N, Vidal Mena D, Alonso A Pascual Martínez M, Caballero Bleda M and Popović M (2020) Verapamil and Alzheimer's Disease: Past,

Present, and Future

Front. Pharmacol. 11:562.

doi: 10.3389/fphar.2020.00562

\title{
Verapamil and Alzheimer's Disease: Past, Present, and Future
}

\author{
Natalija Popović ${ }^{1,2}$, Nicanor Morales-Delgado 1,2,3, David Vidal Mena ${ }^{4}$, Antonia Alonso ${ }^{1,2}$, \\ María Pascual Martínez ${ }^{5}$, María Caballero Bleda ${ }^{1,2}$ and Miroljub Popović ${ }^{1,2 *}$ \\ ${ }^{1}$ Department of Human Anatomy and Psychobiology, Faculty of Medicine, University of Murcia, Murcia, Spain, 2 Institute of \\ Biomedical Research of Murcia (IMIB), Virgen de la Arrixaca University Hospital, University of Murcia, Murcia, Spain, \\ ${ }^{3}$ Department of Histology and Anatomy, Faculty of Medicine, University of Miquel Hernández, Sant Joan Alacant, Spain. \\ ${ }^{4}$ Neurological Unit, University Hospital "Santa Lucia", Cartagena, Spain, 5 Pharmacy Unit, Nursing Home Residence "La \\ Florida", Alicante, Spain
}

Verapamil is a phenylalkylamine class calcium channel blocker that for half a century has been used for the treatment of cardiovascular diseases. Nowadays, verapamil is also considered as a drug option for the treatment of several neurological and psychiatric disorders, such as cluster headache, bipolar disorders, epilepsy, and neurodegenerative diseases. Here, we review insights into the potential preventive and therapeutic role of verapamil on Alzheimer's disease (AD) based on limited experimental and clinical data. Pharmacological studies have shown that verapamil has a wide therapeutic spectrum, including antihypertensive, anti-inflammatory, and antioxidative effects, regulation of the blood-brain barrier function, due to its effect on P-glycoprotein, as well as adjustment of cellular calcium homeostasis, which may result in the delay of AD onset or ameliorate the symptoms of patients. However, the majority of the AD individuals are on polypharmacotherapy, and the interactions between verapamil and other drugs need to be considered. Therefore, for an appropriate and successful AD treatment, a personalized approach is more than necessary. A well-known narrow pharmacological window of verapamil efficacy may hinder this approach. It is therefore important to note that the verapamil efficacy may be conditioned by different factors. The onset, grade, and brain distribution of $A D$ pathological hallmarks, the time-sequential appearances of $A D$-related cognitive and behavioral dysfunction, the chronobiologic and gender impact on calcium homeostasis and $\mathrm{AD}$ pathogenesis may somehow be influencing that success. In the future, such insights will be crucial for testing the validity of verapamil treatment on animal models of $A D$ and clinical approaches.

Keywords: Alzheimer's disease, emotion, learning, memory, verapamil 


\section{INTRODUCTION}

Alzheimer's disease (AD) is one of the most widespread types of irreversible dementia among the older population. It is clinically characterized by a progressive cognitive decline (e.g. memory loss, difficulties in learning new tasks, problems with attention and orientation), behavioral changes (e.g. anxiety, depression, and sleep-wake cycle alterations), and inability to maintain activities of daily living (Lyketsos et al., 2011; Atri, 2019).

The early-onset form of $\mathrm{AD}$ (age $<65$ years) is distinguished by a rapid progression and is linked to the dominant mutations in amyloid precursor protein (APP) and presenilin proteins 1 and 2 (PS 1 and PS2). Mutation in the apolipoprotein E (ApoE) gen, is related to the sporadic late-onset variation of $\mathrm{AD}$ (age $>65$ years). This form, present in the majority of $\mathrm{AD}$ population, is considered multifactorial, since both genetic predisposition and several other factors contribute to the progression of the disease. Excepting aging as the major determinant, other risk factors are more modifiable including lifestyle habits (mental, physical, and social activities, smoking, nutrition), cardiovascular risk factors (obesity, diabetes mellitus, hypertension, etc.), and head injury (Hersi et al., 2017).

The main AD neuropathological features are the presence of extracellular amyloid deposits (senile plaques) in the brain parenchyma and cerebral blood vessels as well as intracellular neurofibrillary tangles accumulation (Love and Miners, 2016; Cline et al., 2018). Amyloid deposits are composed of abnormally folded amyloid $\beta$ (A $\beta$ ) peptides with 40 or 42 amino acids, produced by sequential cleavage of the transmembrane APP, via $\beta$ and $\boldsymbol{\gamma}$-secretase enzymes. Intracellular neurofibrillary tangles are formed by an accumulation of hyperphosphorylated and misfolded tau protein. The neuropathological hallmarks are accompanied by extensive microglia cells and astrocyte activation, the key event in neuroinflammation (McGeer et al., 1989; Eikelenboom et al., 1994; Popović et al., 1998a; Henaka et al., 2015; Kim et al., 2019). These cells produce cytokines (interleukins (ILs), tumor necrosis factors (TNFs), transforming growth factors (TGFs), and interferons (IFN). In AD, some of them have pro-inflammatory (IL-1 $\beta, T N F \alpha$, and IFN- $\gamma$ ), antiinflammatory (IL-4, IL-10, and TGF- $\beta$ ) or even both properties (IL-6) (McGeer and McGeer, 2010; Frost et al., 2019).

Both $A \beta$ peptides and PS are implicated in the intracellular $\mathrm{Ca}^{2+}$ dyshomeostasis (Khachaturian, 1989; Bezprozvanny and Mattson, 2008; Demuro et al., 2010; Alzheimer's Association Calcium Hypothesis, 2017; Pchitskaya et al., 2018). The A $\beta$ peptides produce an excessive elevation in intracellular $\mathrm{Ca}^{2+}$ through the formation of $\mathrm{Ca}^{2+}$-permeable pores in the plasma membrane or increasing $\mathrm{Ca}^{2+}$ influx via activation of L-type $\mathrm{Ca}^{2+}$ channels and $\mathrm{N}$ methyl-D-aspartate (NMDA) receptors. Mutated PSs may form passive $\mathrm{Ca}^{2+}$-leak channels on the endoplasmic reticulum, and together with enhanced ryanodine and inositol 1,4,5-trisphosphate receptors function, augment $\mathrm{Ca}^{2+}$ level in the cytoplasm and mitochondria (Wang and Zheng, 2019). The dysregulation of cellular $\mathrm{Ca}^{2+}$ homeostasis in aging and $\mathrm{AD}$ leads to mitochondrial dysfunction, increased production of reactive oxygen species, autophagy, impaired synaptic plasticity, reduced long-term potentiation (LTP), enhanced long-term depression, synaptic loss, cell death, and eventually cognitive decline (Disterhoft et al., 1994; LaFerla, 2002; Thibault et al., 2007; Murchison et al., 2009; Tönnies and Trushina, 2017; Peineau et al., 2018; Liu and Li, 2019). Therefore, targeting the disturbed calcium homeostasis is one plausible option for the prevention and therapy of $\mathrm{AD}$.

Verapamil $\left(\mathrm{C}_{27} \mathrm{H}_{38} \mathrm{~N}_{2} \mathrm{O}_{4}\right)$, a generic name for iproveratril, which was discovered in the mid-1960s, belongs to the first generation of the phenylalkylamine class of calcium channel antagonists (Fleckenstein, 1977; Nayler and Dillon, 1986), and it is commercialized as a racemic mixture of levo (S) and dextro (R) enantiomers. Verapamil causes dilatation of the main coronary and systemic arteries and decreases myocardial contractility (Fleckenstein, 1977; Nayler and Dillon, 1986). Therefore, for many years it has been deployed as a treatment option for cardiovascular diseases, such as hypertension (Lewis et al., 1978; Midtbø et al., 1986), supraventricular tachyarrhythmias (Schamroth et al., 1972; Krikler \& Spurrell, 1974), and angina pectoris (Livesley et al., 1973; Parodi et al., 1979). Remarkably, verapamil has been also used as a drug option for the treatment of hypertrophic and keloid scars (Ahuja and Chatterjee, 2014; Verhiel et al., 2015), obesity-associated autophagy defects and fatty liver pathologies (Park and Lee, 2014), osteoarthritis (Matta et al., 2015), cluster headache (Meyer and Hardenberg, 1983; Tfelt-Hansen and Tfelt-Hansen, 2009; Leone et al., 2017; Petersen et al., 2019), bipolar disorders (Wisner et al., 2002; Cipriani et al., 2016; Dubovsky, 2018), type 2 diabetes (Yin et al., 2017; Carvalho et al., 2018; Carnovale et al., 2019), chronic rhinosinusitis (Miyake et al., 2018), Peyronie's disease (Russo et al., 2018), tuberculosis (Rayasam and Balganesh, 2015; Song and $\mathrm{Wu}, 2016$ ), epilepsy (Nicita et al., 2016; Turner and Perry, 2017), and reversible cerebral vasoconstriction syndrome (Cappelen-Smith et al., 2017). However, verapamil has expressed ambiguous effects in Parkinson's disease (GarcíaAlbea et al., 1993; Pasternak et al., 2012) and dementia (Maxwell et al., 1999; Yaser et al., 2005; Nimmrich and Eckert, 2013).

The aim of this mini review is to bring together data about the potential effects of verapamil on the prevention and therapy of $\mathrm{AD}$, and highlights some concerns for future research.

\section{ALZHEIMER'S DISEASE AND VERAPAMIL}

\section{Experimental Findings \\ Ex Vivo Studies}

It has been demonstrated that verapamil ameliorated the neurotoxicity caused by $A \beta$ and reduces the $A \beta_{1-40}$ oligomer levels by improving their efflux from the LS-180 cells, via Pglycoprotein up-regulation (Abuznait et al., 2011). Verapamil also restores the microtubule-binding activity of tau and ameliorates the level of oxidative stress in the SH-SY5Y neuroblastoma cell line exposed to $A \beta_{1-42}$ (Melone et al., 2018). Physiological studies indicated that the $A \beta_{25-35}$-induced depression of LTP in a hippocampal slice preparation may be attenuated by verapamil (Freir et al, 2003). Furthermore, this drug protected MC65 neuroblastoma cells from the APP C-terminal fragment-induced 
neurotoxicity (Anekonda et al., 2011). However, Whitson and Appel (1995) demonstrated the inefficiency of verapamil in the prevention of $A \beta_{1-40}$ neurotoxicity in a pure hippocampal neuronal culture, suggesting that glial-neuronal interaction is important for the preventive effect of verapamil. The rise of $\mathrm{Ca}^{2+}$ concentration was inhibited by verapamil in a human microglia cells culture treated with $\mathrm{A} \beta_{25-35}$ (Silei et al., 1999).

Verapamil pre-treatment protects IMR-32 cells against the scopolamine-induced cytotoxicity, attenuates oxidative stress, and prevents mitochondrial damage (Ponne et al., 2019). It also augments the expression of genes involved in the cholinergic function (mACR1), $\mathrm{Ca}^{2+}$-dependent memory-related genes (CREB1, CREBBP, BDNF), and synaptic plasticity (GAP43, SYP) that were downregulated by scopolamine (Ponne et al., 2019). Nevertheless, the lipopolysaccharide neurotoxicity in mesencephalic dopaminergic neurons that are dependent on microglia activation and augmented production of proinflammatory factors (superoxide, NO, and TNF- $\alpha$ ) may be abolished by verapamil treatment (Liu et al., 2011). Similarly, verapamil significantly reduces IFN- $\gamma$;-induced neurotoxicity of human astrocytes to SH-SY5Y neuroblastoma cells (Hashioka et al., 2012). Moreover, both $\mathrm{R}$ and S-isomers of verapamil show equivalent potency to reduce the microglia-mediated neurotoxicity, even though the R-isomer has much less activity to block L-type calcium channels than the $S$ counterpart (Liu et al., 2011).

\section{In Vivo Studies}

Nucleus basalis of Meynert (in non-human animals correspond to the nucleus basalis magnocellularis-NBM) is composed of numerous cholinergic neurons that are affected in $\mathrm{AD}$ (Whitehouse et al., 1981; Rinne et al., 1987). Therefore, the lesion of this area was taken as an animal model of AD. Studies from our group with rats supported that verapamil, given in doses of 2.5 and $5 \mathrm{mg} / \mathrm{kg}$, ameliorated the effect of NBM electrolytic lesions on learning and memory in active avoidance test (Popovic et al., 1997a), anxiety behavior in open field test (Popovic et al., 1997b), learned helplessness-induced depression (Popovic et al., 1998b), and body temperature (Popovic et al., 1998c). Findings that acute verapamil treatment (5 and $10 \mathrm{mg} / \mathrm{kg}$ ), in NBM-lesioned rats, abolished cold restraint induced gastric petechiae, while in control rats, it diminished gastric erosion formation, suggest that the verapamil effect may be modified by stress (Popovic et al., 1999). The long-term treatment with verapamil in NBM-lesioned rats prevented the impairments in active avoidance memory, open field behavior, and performance in learning helplessness tests (Popović et al., 1997c). Neither acute nor chronic verapamil treatment improved foot-shock induced aggression in NBM-lesioned rats (Popović et al., 1997c; Popović et al., 1998b, respectively). Moreover, morphological studies indicated that long-term verapamil treatment $(2.5,5$, and $10 \mathrm{mg} / \mathrm{kg} / 12 \mathrm{~h})$ produced a significant neuroprotection on NADPH-diaphorase and ChATimmunopositive cortical neurons in NBM lesioned rats (CaballeroBleda et al., 2001; Popovic et al., 2006). The above-mentioned studies indicated that verapamil expresses an inverted U-shape mode of action (Tables $\mathbf{1}$ and 2).
Systemic administration of scopolamine, a non-selective muscarinic receptor antagonist, has been considered as a pharmacological model of AD (Kwon et al., 2010; Pandareesh and Anand, 2013; Xiao et al., 2014). Long-term verapamil treatment, in a dose of $10 \mathrm{mg} / \mathrm{kg}$ (but not in a dose of $5 \mathrm{mg} / \mathrm{kg}$ ), attenuated the increased mouse locomotion induced by scopolamine (Ponne et al., 2019). However, verapamil in both used doses, improved memory deficit in the elevated plus maze task and passive avoidance test, reversed the increased acetylcholinesterase (AChE) activity, and preserved the mouse brain from the oxidative stress induced by scopolamine (Ponne et al., 2019). Prophylactic and curative treatment by verapamil significantly abolished scopolamine-induced impairment in both the elevated plus maze test and the novel object recognition task in female rats (Sekhar et al., 2016). The above-mentioned treatment significantly enhanced oxidative stress markers that were decreased by scopolamine and reduced the enhanced AChE level. Furthermore, verapamil, given in a dose of $10 \mathrm{mg} / \mathrm{kg}$, prevented the anti-depressive effect of scopolamine in rats tested in forced swim and novelty suppressed feeding tests. In the same animals, verapamil blocked the scopolamine-induced increase of the brainderived neurotrophic factor (BDNF)/TrkB activation in the prefrontal cortex (Ghosal et al., 2018). Similarly, verapamil (5 $\mathrm{mg} / \mathrm{kg}$ ) significantly blockaded: 1) the scopolamine antidepressant-like effect, in mice tested in a forced swimming test; and 2) scopolamine upregulated the effect on BDNF and neuropeptide VGF (nonacronymic) content, in the hippocampus and prefrontal cortex (Yu et al., 2018). However, verapamil failed to abolish scopolamine-induced amnesia in the novel object recognition test (Yu et al., 2018) (Tables 1 and 2). Our recent study, focused on a passive avoidance task in rats, demonstrated that verapamil, at the dose that per se does not affect the memory consolidation, significantly reversed the memory consolidation improvement induced by scopolamine (Giménez de Bejar et al., 2017).

Intracerebroventricular injection (icv) of streptozotocin (STZ) has been described as an experimental model for sporadic AD (Kumar et al., 2016). In this rat model, chronic verapamil treatment $(2.5$ and $5 \mathrm{mg} / \mathrm{kg}$ ) significantly improved memory in both the elevated plus maze test and the Morris water maze task (Kumar et al., 2016). Moreover, at mentioned doses, verapamil attenuated $\mathrm{AChE}$ activity in the hippocampus and frontal cortex. However, only the higher verapamil dose attenuated the oxidative stress damage and the level of TNF- $\alpha$ in the hippocampus and frontal cortex of icv-STZ-injected rats (Kumar et al., 2016) (Table 1). At the same dose, verapamil significantly reduced number of apoptotic pyramidal cells at the CA3 hippocampal region.

The icv administration of peptide $\mathrm{A} \beta_{25-35}$ in adult Wistar rats causes depression of LTP in the hippocampal CA1 area. This depression is significantly reversed by intraperitoneal administration of $1 \mathrm{mg} / \mathrm{kg}$ of verapamil, and with less efficacy at $10 \mathrm{mg} / \mathrm{kg}$ (Freir et al., 2003).

Verapamil ( $1 \mathrm{mg} / \mathrm{kg} /$ day), given orally (drinking water) for 3 months, inhibits A $\beta$ formation and Ser202/Thr205 phosphorylation of tau by blocking the TXNIP/ROS/p38 
TABLE 1 | Effect of verapamil $(M)$ on learning and memory in three animal models of Alzheimer's disease (AD): nucleus basalis magnocellularis (NBM) lesion, scopolamine (S) treatment, and intracerebroventricular injection (icv) of streptozotocin (STZ).

\begin{tabular}{|c|c|c|c|c|c|c|c|c|c|c|}
\hline $\begin{array}{l}\text { AD model/ } \\
\text { reference }\end{array}$ & $\begin{array}{c}\text { Experimental } \\
\text { animal }\end{array}$ & \multicolumn{2}{|c|}{ Treatment } & \multicolumn{2}{|c|}{ Active avoidance } & $\begin{array}{c}\text { Elevated } \\
\text { plus } \\
\text { maze- } \\
\text { retention }\end{array}$ & $\begin{array}{l}\text { Passive } \\
\text { avoidance } \\
\text { - reten- } \\
\text { tion }\end{array}$ & $\begin{array}{l}\text { Novel } \\
\text { object rec- } \\
\text { ognition- } \\
\text { retention }\end{array}$ & \multicolumn{2}{|c|}{ Morris water maze } \\
\hline $\begin{array}{l}\text { NBM-lesion/ } \\
\text { Popović et al., } \\
1997 a\end{array}$ & $\begin{array}{l}\text { Wistar rats } \\
\text { Young adult } ₫\end{array}$ & $\begin{array}{l}\text { Saline } \\
\text { V } 1 \\
\text { V } 2.5 \\
\text { V } 5 \\
\text { V } 10\end{array}$ & $\begin{array}{l}\text { s.c., } 30 \text { min before } \\
\text { test. Test } \\
\text { performed } 10 \text { days } \\
\text { after lesion. }\end{array}$ & $\begin{array}{c}\downarrow \\
\text { ns } \\
p<0.05 \uparrow \\
p<0.01 \uparrow \\
\text { ns }\end{array}$ & $\begin{array}{c}\downarrow \\
\mathrm{ns} \\
p<0.05 \uparrow \\
p<0.01 \uparrow \\
\mathrm{ns}\end{array}$ & & & & & \\
\hline $\begin{array}{l}\text { NBM-lesion/ } \\
\text { Popović et al., } \\
\text { 1997c }\end{array}$ & $\begin{array}{l}\text { Wistar rats } \\
\text { Young adult }{ }^{\star}\end{array}$ & $\begin{array}{l}\text { Saline } \\
\text { V } 1 \\
\text { V } 2.5 \\
\text { V } 5 \\
\text { V } 10\end{array}$ & $\begin{array}{l}\text { i.p., } 24 \text { h after } \\
\text { lesion in duration of } \\
8 \text { days (every } 12 \text { h). } \\
\text { Test performed } 13 \\
\text { days after lesion. }\end{array}$ & & $\begin{array}{c}\downarrow \\
\mathrm{ns} \\
p<0.05 \uparrow \\
p<0.01 \uparrow \\
\mathrm{ns}\end{array}$ & & & & & \\
\hline $\begin{array}{l}\text { Scopolamine, } 3 \\
\mathrm{mg} / \mathrm{kg} \text { i.p./Ponne } \\
\text { et al., } 2019\end{array}$ & $\begin{array}{l}\text { Swiss mice } \\
\text { Young adult o }\end{array}$ & $\begin{array}{l}\text { S } 3 \\
\text { S } 3+V 5 \\
\text { S } 3+V 10\end{array}$ & $\begin{array}{l}\text { i.p., } 7 \text { days, last } \mathrm{V} \\
\text { dose } 60 \mathrm{~min} \text { before } \\
\mathrm{S} \text { and } 90 \mathrm{~min} \\
\text { before test }\end{array}$ & & & $\begin{array}{c}\downarrow \\
\text { ns } \\
p<0.05 \uparrow\end{array}$ & $\begin{array}{c}\downarrow \\
p<0.05 \uparrow \\
p<0.05 \uparrow\end{array}$ & & & \\
\hline $\begin{array}{l}\text { Scopolamine: } 0.9 \\
\text { mg/kg i.p., } 7 \text { days/ } \\
\text { Sekhar et al., } 2016\end{array}$ & $\begin{array}{l}\text { Wistar rats } \\
\text { Young adult o }\end{array}$ & S 0.9 & $\begin{array}{l}\text { p.o., } 7 \text { days, } \vee 30 \\
\text { min: }\end{array}$ & & & $\downarrow$ & & $\downarrow$ & & \\
\hline & & $\begin{array}{l}\vee 21.6 \\
\text { V } 21.6\end{array}$ & $\begin{array}{l}\text { - before S } \\
\text { - after S }\end{array}$ & & & $\begin{array}{l}p<0.05 \uparrow \\
p<0.01 \uparrow\end{array}$ & & $\begin{array}{l}p<0.05 \uparrow \\
p<0.05 \uparrow\end{array}$ & & \\
\hline $\begin{array}{l}\text { Scopolamine: i.p., } \\
0.025 \text { mg/kg, } 0.05 \\
\mathrm{mg} / \mathrm{kg}, 0.1 \mathrm{mg} / \mathrm{kg} \text {, } \\
1 \mathrm{mg} / \mathrm{kg}, 3 \mathrm{mg} / \mathrm{kg} / \\
\text { Yu et al., } 2018\end{array}$ & $\begin{array}{l}\text { C57BL/6J } \\
\text { mice } \\
\text { Young adult ơ }\end{array}$ & $\begin{array}{l}\text { S } 0.025 \\
\text { S } 0.05 \\
\text { S } 0.1 \\
\text { S } 1 \\
\text { S } 3 \\
\text { S } 0.025+V \\
5 \\
\text { S } 1+V 5 \\
\text { S } 3+V 5\end{array}$ & $\begin{array}{l}\text { i.p., V } 60 \text { min } \\
\text { before S }\end{array}$ & & & & & $\begin{array}{c}\text { ns } \\
\text { ns } \\
\text { ns } \\
\downarrow \\
\downarrow \\
\text { ns } \\
\\
\text { ns } \\
\text { ns }\end{array}$ & & \\
\hline
\end{tabular}

s.c., subcutaneous; i.p., intraperitoneal; p.o., oral.

$\uparrow$ cognitive improvement; $\downarrow$ cognitive impairment.

MAPK pathway in the hippocampus of $5 \mathrm{xFAD}$ transgenic mice (Melone et al., 2018).

\section{Clinical Findings}

Studies on AD patient brains have shown that phenylalkylamines receptor binding parameters, $\mathrm{K}_{\mathrm{D}}$ (affinity) and $\mathrm{B}_{\max }$ (density), are not affected in frontal, temporal, parietal, and occipital cortices, hippocampus, striatum, and thalamus (Sen et al., 1993), suggesting, altogether, that clinical trials with verapamil should not be impeded by the functionality of these receptors. One limited prospective study indicated that the use of verapamil neither significantly reduced the risk of developing AD nor had an effect on the risk of all-cause mortality (Yaser et al., 2005).

\section{Particularities of Mechanism of Action of Verapamil: Pros and Cons}

Although initially considered as an L-type $\mathrm{Ca}^{2+}$ channel blocker (Cav1.2 and Cav1.3 alpha subunits), verapamil also binds the alpha subunits of P/Q type (Cav2.1), N-type (Cav2.2), R-type
(Cav2.3), and T-type (Cav3.1 and Cav3.2) calcium channels (Ishibashi et al., 1995; Cai et al., 1997; Dobrev et al., 1999; Tarabova et al., 2007; Kuryshev et al., 2014). Both Cav1.2 and Cav1.3 alpha subunits are similarly upregulated at the surface level in rat cultured hippocampal neurons exposed to the $A \beta_{25-35}$ (Kim and Rhim, 2011). On one hand, a study performed in 2, 4and 11-month transgenic mice, overexpressing hA $\beta$ PP751 with the London (V717I) and Swedish (K670M/N671L) mutations, indicated that the expression of Cav1.2 $\alpha 1$-subunits in reactive astrocytes, is related to the increased amyloid- $\beta$ load in the plaques (Daschil et al., 2013). On the other hand, a blockade of the Cav3.1 T-type channel reduces non-amyloidogenic processing and produces higher levels of $A \beta$ peptide in the brain of $3 \times \mathrm{Tg}-\mathrm{AD}$ mice aged 14 to 16 months (Rice et al., 2014). The pathological, aggregated form of $A \beta_{1-40}$, reduced $\mathrm{Ca}^{2+}$ channel current density in cortical neurons, via an action on N-type calcium channels (Ramsden et al., 2002), as well as $\mathrm{A} \beta_{1-42}$ globulomer inhibited presynaptic P/Q calcium currents in hippocampal cells (Nimmrich et al., 2008). These findings 
TABLE 2 | Effect of verapamil (M) on anxiety-like behavior (open field and elevated plus maze tests), depressive-like behavior (learned helplessness, forced swimming and novelty suppressed tests) and aggression (footshock aggression) in two animal models of Alzheimer's disease (AD): nucleus basalis magnocellularis (NBM) lesion and scopolamine (S).

\begin{tabular}{|c|c|c|c|c|c|c|c|c|c|c|c|c|}
\hline \multirow[t]{2}{*}{ AD model/reference } & \multirow{2}{*}{$\begin{array}{l}\text { Experimental } \\
\text { animal }\end{array}$} & \multicolumn{2}{|r|}{ Treatment } & \multicolumn{4}{|c|}{ Open field } & \multirow{2}{*}{$\begin{array}{l}\text { Elevated } \\
\text { plus } \\
\text { maze }\end{array}$} & \multirow{2}{*}{$\begin{array}{c}\text { Learned } \\
\text { helplessness }\end{array}$} & \multirow{2}{*}{$\begin{array}{l}\text { Forced } \\
\text { swimming } \\
\text { test }\end{array}$} & \multirow{2}{*}{$\begin{array}{l}\text { Novelty } \\
\text { suppressed } \\
\text { feeding }\end{array}$} & \multirow{2}{*}{$\begin{array}{c}\text { Foot- } \\
\text { shock } \\
\text { aggression }\end{array}$} \\
\hline & & $\begin{array}{c}\text { Drug/dose } \\
\text { (mg/kg) }\end{array}$ & $\begin{array}{l}\text { Administration route } \\
\text { and schedule }\end{array}$ & Ambulation & Rearing & $\begin{array}{l}\text { Activity in } \\
\text { the } \\
\text { center }\end{array}$ & Defecation & & & & & \\
\hline $\begin{array}{l}\text { NBM-lesion/Popović et al., } \\
\text { 1997b }\end{array}$ & $\begin{array}{l}\text { Wistar rats } \\
\text { Young adult to }\end{array}$ & $\begin{array}{l}\text { Saline } \\
\text { V } 1 \\
\text { V } 2.5 \\
\text { V } 5 \\
\text { V } 10\end{array}$ & $\begin{array}{l}\text { s.c., } 30 \text { min before test. } \\
\text { Test performed } 10 \text { days } \\
\text { after lesion. }\end{array}$ & $\begin{array}{c}\uparrow \\
\text { ns } \\
p<0.001 \downarrow \\
p<0.01 \downarrow \\
\text { ns }\end{array}$ & $\begin{array}{l}\text { ns } \\
\text { ns } \\
\text { ns } \\
\text { ns } \\
\text { ns }\end{array}$ & $\begin{array}{c}\uparrow \\
\mathrm{ns} \\
p<0.001 \downarrow \\
p<0.01 \downarrow \\
\mathrm{ns}\end{array}$ & $\begin{array}{c}\downarrow \\
\mathrm{ns} \\
p<0.05 \uparrow \\
\mathrm{ns} \\
\mathrm{ns}\end{array}$ & & & & & \\
\hline $\begin{array}{l}\text { NBM-lesion/Popović et al., } \\
\text { 1997c }\end{array}$ & $\begin{array}{l}\text { Wistar rats } \\
\text { Young adult o }\end{array}$ & $\begin{array}{l}\text { Saline } \\
\text { V } 1 \\
\text { V } 2.5 \\
\text { V } 5 \\
\text { V } 10\end{array}$ & $\begin{array}{l}\text { i.p., } 24 \mathrm{~h} \text { after lesion in } \\
\text { duration of } 8 \text { days (every } \\
\text { 12h). Test performed } 13 \\
\text { days after lesion. }\end{array}$ & $\begin{array}{c}\uparrow \\
\text { ns } \\
p<0.001 \downarrow \\
p<0.001 \downarrow \\
\text { ns }\end{array}$ & $\begin{array}{l}\text { ns } \\
\text { ns } \\
\text { ns } \\
\text { ns } \\
\text { ns }\end{array}$ & $\begin{array}{c}\uparrow \\
\text { ns } \\
p<0.01 \downarrow \\
p<0.001 \downarrow \\
\text { ns }\end{array}$ & $\begin{array}{c}\downarrow \\
\text { ns } \\
p<0.001 \uparrow \\
p<0.01 \uparrow \\
\text { ns }\end{array}$ & & $\begin{array}{c}\downarrow \\
\mathrm{ns} \\
p<0.05 \uparrow \\
p<0.001 \uparrow \\
\mathrm{ns}\end{array}$ & & & $\begin{array}{l}\downarrow \\
\text { ns } \\
\text { ns } \\
\text { ns } \\
\text { ns }\end{array}$ \\
\hline $\begin{array}{l}\text { NBM lesion/Popović et al., } \\
\text { 1997c }\end{array}$ & $\begin{array}{l}\text { Wistar rats } \\
\text { Young adult }{ }^{\star}\end{array}$ & $\begin{array}{l}\text { Saline } \\
\text { V } 1 \\
\text { V2.5 } \\
\text { V } 5 \\
\text { V } 10\end{array}$ & $\begin{array}{l}\text { s.c., } 30 \text { min before test. } \\
\text { Test performed } 10 \text { days } \\
\text { after lesion. }\end{array}$ & & & & & & $\begin{array}{c}\downarrow \\
\text { ns } \\
p<0.05 \uparrow \\
p<0.05 \uparrow \\
\text { ns }\end{array}$ & & & $\begin{array}{l}\downarrow \\
\text { ns } \\
\text { ns } \\
\text { ns } \\
\text { ns }\end{array}$ \\
\hline $\begin{array}{l}\text { Scopolamine: } 3 \text { mg/kg i.p./ } \\
\text { Ponne et al., } 2019\end{array}$ & $\begin{array}{l}\text { Swiss mice } \\
\text { Young adult to }\end{array}$ & $\begin{array}{l}\text { S } 3 \\
\text { S } 3+V 5 \\
\text { S } 3+V 10\end{array}$ & $\begin{array}{l}\text { i.p., } 7 \text { days, last } V \text { dose } \\
60 \text { min before } S \text { and } 90 \\
\text { min before test }\end{array}$ & & & & & $\begin{array}{c}\uparrow \\
\mathrm{ns} \\
p<0.05 \downarrow\end{array}$ & & & & \\
\hline $\begin{array}{l}\text { Scopolamine: } 0.025 \text { mg/kg i.p./ } \\
\text { Ghosal et al., } 2018\end{array}$ & $\begin{array}{l}\text { Sprague- } \\
\text { Dawley rats } \\
\text { Young adult o }\end{array}$ & $\begin{array}{l}\text { S } 0.025 \\
\text { S } 0.025+V \\
10\end{array}$ & $\begin{array}{l}3 \text { doses every other day } \\
\text { i.p. } \\
\text { i.p, } \vee 30 \text { min before } S\end{array}$ & & & & & & & $\begin{array}{c}\downarrow \\
p<0.05 \uparrow\end{array}$ & $\begin{array}{c}\downarrow \\
p<0.05 \uparrow\end{array}$ & \\
\hline $\begin{array}{l}\text { Scopolamine: i.p., } 0.025 \text { mg/kg, } \\
0.05 \text { mg/kg, } 0.1 \text { mg/kg, } 1 \text { mg/ } \\
\text { kg, } 3 \text { mg/kg/Yu et al., } 2018\end{array}$ & $\begin{array}{l}\text { C57BL/6J } \\
\text { mice } \\
\text { Young adult o }\end{array}$ & $\begin{array}{l}\text { S } 0.025 \\
\text { S } 0.05 \\
\text { S } 0.1 \\
\text { S } 1 \\
\text { S } 3 \\
\text { S } 0.025+ \\
\text { V } 5 \\
\text { S } 1+\text { V } 5 \\
\text { S } 3+\text { V } 5\end{array}$ & i.p., $\vee 60 \mathrm{~min}$ before $\mathrm{S}$ & $\begin{array}{l}\text { ns } \\
\text { ns } \\
\text { ns } \\
\text { ns } \\
\text { ns } \\
\text { ns } \\
\text { ns } \\
\text { ns }\end{array}$ & $\begin{array}{l}\text { ns } \\
\text { ns } \\
\text { ns } \\
\text { ns } \\
\text { ns } \\
\text { ns } \\
\text { ns } \\
\text { ns }\end{array}$ & & & & & $\begin{array}{c}\downarrow \\
\downarrow \\
\text { ns } \\
\uparrow \\
\uparrow \\
p<0.05 \uparrow \\
\\
\text { ns } \\
\text { ns }\end{array}$ & & \\
\hline
\end{tabular}

$\uparrow$ increase values of measured behavioral parameters; $\downarrow$ decrease values of measured behavioral parameters. 
pinpointed that verapamil may have a beneficial effect on L-type $\mathrm{Ca}^{2+}$ channels but not on P/Q-type, N-type and T-type $\mathrm{Ca}^{2+}$ channels.

However, verapamil, as a small conductance calciumactivated potassium channels (SK channel) antagonist (Tao et al., 2013), may have a dual effect: improve memory but fail to have a neuroprotective role in AD (Lam et al., 2013).

Besides its general action as inhibitor of the transmembrane influx of extracellular calcium ions, verapamil, in several brain regions (e.g. cerebral cortex, hippocampus, hypothalamus), acts as an antagonist of muscarinic (Baumgold, 1986; Popova et al., 1990), $\alpha$ - and $\beta$-adrenergic (Galzin and Langer, 1983; StanevaStoytcheva et al., 1990; Staneva-Stoytcheva et al., 1992), dopaminergic (Sitges and Guarneros, 1998), serotoninergic (Taylor and Defeudis, 1984; Adachi and Shoji, 1986; Green et al., 1990; Popova et al., 1991; Shad and Saeed, 2007), and GABAergic receptors (Staneva-Stoytcheva et al., 1991). Thus, it is likely from these findings and the impairments of cholinergic (Hampel et al., 2018), GABAergic (Li et al., 2016), and monoaminergic transmission (Šimić et al., 2017) in AD disease that verapamil could modify the neurotransmission in AD.

$\mathrm{P}$-glycoprotein is a transmembrane glycoprotein localized in several barriers (e.g. blood-brain barrier (BBB), bloodcerebrospinal fluid barrier (BCSFB)). Its presence on the luminal membrane of the endothelial cells at the $\mathrm{BBB}$ (Beaulieu et al., 1997), restricts the entry of an exogenous compound (e.g., drugs, xenobiotics, toxins) into the brain and also regulates the cellular efflux from the brain. Most of the studies support that $\mathrm{P}$-glycoprotein is important for $\mathrm{A} \beta_{1-40}$ and $\mathrm{A} \beta_{1-42}$ clearance, and that dysfunction of this process might lead to AD development (Lam et al., 2001; Vogelgesang et al., 2002; Vogelgesang et al., 2004; Cirrito et al., 2005; Kuhnke et al., 2007; Silverberg et al., 2010). Furthermore, microglia activation and, consequently, secretion of pro-inflammatory cytokines can disturb the P-glycoprotein production and function. On one hand, verapamil as P-glycoprotien inhibitor (Bendayan et al., 2002) may diminish the efflux of $A \beta_{1-40}$ and $A \beta_{1-42}$, while, on the other hand, it may restrain the pro-inflammatory processes and permit the entrance of some beneficial drugs, too.

During normal aging, there is a progressive decline in the $\mathrm{BBB}$ P-glycoprotein activity, particularly in men but not in women, that can lead to the accumulation of harmful compounds in the brain parenchyma (Bartels, 2011; van Assema et al., 2012a). Furthermore, the decreased BBB P-glycoprotein function in young women, compared with young men, may implicate an increased risk of AD in women (van Assema et al., 2012a). Nowadays, R- $\left[{ }^{11} \mathrm{C}\right]$ verapamil isomer is being used for the evaluation of the blood-brain barrier function in aging and $\mathrm{AD}$, since its high uptake as radiotracer indicates decreased $\mathrm{P}$ glycoprotein functionality in these conditions (Luurtsema et al., 2003; van Assema et al., 2012b; Chai et al., 2019).

Intriguingly, low and high systolic blood pressure trajectories from mid- to late-life have been associated with cognitive deficit and increased risk of AD (Skoog et al., 1996; Kivipelto et al., 2001; Qiu et al., 2004; McGrath et al., 2017). The daily fluctuations of blood pressure highlight the importance of synchronizing antihypertensive therapy with time of day (Hermida et al., 2005; Hermida et al., 2007). Similarly, the half-life of verapamil during the evening dosing regimen is much longer than the morning treatment (Jespersen et al., 1989). Bearing in mind that intracellular $\mathrm{Ca}^{2+}$ oscillates on a circadian and ultradian rhythm base (Noguchi et al., 2017; Wu et al., 2018) and that circadian rhythm is highly disturbed in AD patients (Coogan et al., 2013) a chronotherapy with verapamil in AD patents should be considered.

Finally, since the age and gender may modify the verapamil pharmacokinetic and pharmacodynamic effect on a stereoselective (S- and R-isomers) base (Schwartz, 1990; Sasaki et al., 1993; Schwartz et al., 1993; Schwartz et al., 1994; Gupta et al., 1995; Schwartz, 1996; Krecic-Shepard et al., 2000; Dadashzadeh et al., 2006), it seems reasonable to consider the Franco and Petrovic (2015) proposal, which suggests testing the efficacy of S- and Rverapamil molecules in $\mathrm{AD}$ models separately.

\section{CONCLUSION}

Experimental data in animal models of $\mathrm{AD}$ indicated a potential positive effect of verapamil in ameliorating $\mathrm{AD}$-like pathology. However, the lack of clinical findings limits its potential use in AD therapy. Probably, instead of a racemic mixture of both isomers, the equilibrate percent of each isomer should be considered. Moreover, the dose used, daytime therapy schedule, and route of verapamil application should be adjusted depending on individual conditions (gender, age, the severity of AD pathology, person's chronotype, etc). Multimorbidity increases with aging and most of the $\mathrm{AD}$ patients are on polypharmacotherapy. Therefore, a possible interaction between verapamil and other drugs needs to be considered. Bearing in mind that presently, more than eight million people, just in the USA, are currently on verapamil treatment, it would seem that a rational approach to personalized AD therapy will not only be beneficial for patients, but it will also decrease the harmful impact of verapamil on the environment (Saari et al., 2017) and health economics.

\section{AUTHOR CONTRIBUTIONS}

All authors managed the literature searches, have read and approved the final manuscript.

\section{FUNDING}

Funding was provided by the Spanish Ministry of Science, Innovation and Universities and European Regional Development Fund (FEDER; PGC2018-098229-B-100). 


\section{REFERENCES}

Abuznait, A. H., Cain, C., Ingram, D., Burk, D., and Kaddoumi, A. (2011). Upregulation of $\mathrm{P}$-glycoprotein reduces intracellular accumulation of beta amyloid: investigation of P-glycoprotein as a novel therapeutic target for Alzheimer's disease. J. Pharm. Pharmacol. 63, 1111-1118. doi: 10.1111/ j.2042-7158.2011.01309.x

Adachi, H., and Shoji, T. (1986). Characteristics of the inhibition of ligand binding to serotonin receptors in rat brain membranes by verapamil. Jpn. J. Pharmacol. 41, 431-435. doi: 10.1254/jjp.41.431

Ahuja, R. B., and Chatterjee, P. (2014). Comparative efficacy of intralesional verapamil hydrochloride and triamcinolone acetonide in hypertrophic scars and keloids. Burns 40, 583-588. doi: 10.1016/j.burns.2013.09.029

Alzheimer's Association Calcium Hypothesis Workgroup (2017). Calcium Hypothesis of Alzheimer's disease and brain aging: a framework for integrating new evidence into a comprehensive theory of pathogenesis. Alzheimer's Dement. 13, 178-182 e117. doi: 10.1016/j.jalz.2016.12.006

Anekonda, T. S., Quinn, J. F., Harris, C., Frahler, K., Wadsworth, T. L., and Woltjer, R. L. (2011). L-type voltage-gated calcium channel blockade with isradipine as a therapeutic strategy for Alzheimer's disease. Neurobiol. Dis. 41, 62-70. doi: 10.1016/j.nbd.2010.08.020

Atri, A. (2019). The Alzheimer's disease clinical spectrum: diagnosis and management. Med. Clin. North. Am. 103, 263-293. doi: 10.1016/ j.mcna.2018.10.009

Bartels, A. L. (2011). Blood-brain barrier P-glycoprotein function in neurodegenerative disease. Curr. Pham. Des. 17, 2771-2777. doi: 10.2174/ 138161211797440122

Baumgold, J. (1986). Effects of verapamil on the binding characteristics of muscarinic receptor subtypes. Eur. J. Pharmacol. 126, 151-154. doi: 10.1016/ 0014-2999(86)90752-1

Beaulieu, E., Demeule, M., Ghitescu, L., and Beliveau, R. (1997). P-glycoprotein is strongly expressed in the luminal membranes of the endothelium of blood vessels in the brain. Biochem. J. 326, 539-544. doi: 10.1042/bj3260539

Bendayan, R., Lee, G., and Bendayan, M. (2002). Functional expression and localization of P-glycoprotein at the blood brain barrier. Microsc. Res. Ech. 57, 365-380. doi: 10.1002/jemt.10090

Bezprozvanny, I., and Mattson, M. P. (2008). Neuronal calcium mishandling and the pathogenesis of Alzheimer's disease. Trends Neurosci. 31, 454-463. doi: 10.1016/j.tins.2008.06.005

Caballero-Bleda, M., Redondo-Aniorte, F. J., Aldeguer-Montiel, A., Popović, N., Popović, M., and Puelles, L. (2001). NADPH-diaphorase activity in the frontal cortex of NBM-lesioned rats treated with verapamil. Neurosci. Res. Commun. 28, 115-122. doi: 10.1002/nrc.1011

Cai, D., Mulle, J. G., and Yue, D. T. (1997). Inhibition of recombinant Ca2+ channels by benzothiazepines and phenylalkylamines: class-specific pharmacology and underlying molecular determinants. Mol. Pharmacol. 51, 872-881. doi: 10.1124/mol.51.5.872

Cappelen-Smith, C., Calic, Z., and Cordato, D. (2017). Reversible cerebral vasoconstriction syndrome: recognition and treatment. Curr. Treat. Options Neurol. 19, 21. doi: 10.1007/s11940-017-0460-7

Carnovale, C., Dassano, A., Mosini, G., Mazhar, F., D’Addio, F., Pozzi, M., et al. (2019). The $\beta$-cell effect of verapamil-based treatment in patients with type 2 diabetes: a systematic review. Acta Diabetol. 57, 117-131. doi: 10.1007/s00592019-01370-1

Carvalho, D. S., de Almeida, A. A., Borges, A. F., and Vannucci Campos, D. (2018). Treatments for diabetes mellitus type II: new perspectives regarding the possible role of calcium and cAMP interaction. Eur. J. Pharmacol. 830, 9-16. doi: 10.1016/j.ejphar.2018.04.002

Chai, A. B., Leung, G. K. F., Callaghan, R., and Gelissen, I. C. (2019). Pglycoprotein: a role in the export of amyloid- $\beta$ in Alzheimer's disease? FEBS J. 287, 612-625. doi: 10.1111/febs.15148

Cipriani, A., Saunders, K., Attenburrow, M. J., Stefaniak, J., Panchal, P., Stockton, S., et al. (2016). A systematic review of calcium channel antagonists in bipolar disorder and some considerations for their future development. Mol. Psychiatry 21, 1324-1332. doi: 10.1038/mp.2016.86

Cirrito, J. R., Deane, R., Fagan, A. M., Spinner, M. L., Parsadanian, M., Finn, M. B., et al. (2005). P-glycoprotein deficiency at the blood-brain barrier increases amyloid-beta deposition in an Alzheimer disease mouse model. J. Clin. Invest. 115, 3285-3290. doi: 10.1172/JCI25247

Cline, E. N., Bicca, M. A., Viola, K. L., and Klein, W. L. (2018). The amyloid- $\beta$ oligomer hypothesis: beginning of the third decade. J. Alzheimer's Dis. 64 (s1), S567-S610. doi: 10.3233/JAD-179941

Coogan, A. N., Schutová, S., Husung, S., Furczyk, K., Baune, B. T., Kropp, P., et al. (2013). The circadian system in Alzheimer's disease: disturbances, mechanisms, and opportunities. Biol. Psychiatry 74, 333-339. doi: 10.1016/ j.biopsych.2012.11.021

Dadashzadeh, S., Javadian, B., and Sadeghian, S. (2006). The effect of gender on the pharmacokinetics of verapamil and norverapamil in human. Biopharm. Drug Dispos. 27, 329-334. doi: 10.1002/bdd.512

Daschil, N., Obermair, G. J., Flucher, B. E., Stefanova, N., Hutter-Paier, B., Windisch, M., et al. (2013). Cav1.2 calcium channel expression in reactive astrocytes is associated with the formation of amyloid- $\beta$ plaques in an Alzheimer's disease mouse model. J. Alzheimer's Dis. 37, 439-451. doi: 10.3233/JAD-130560

Demuro, A., Parker, I., and Stutzmann, G. E. (2010). Calcium signaling and amyloid toxicity in Alzheimer disease. J. Biol. Chem. 285, 12463-12468. doi: 10.1074/jbc.R109.080895

Disterhoft, J. F., Moyer, J. R.Jr., and Thompson, L. T. (1994). The calcium rationale in aging and Alzheimer's disease. Evidence from an animal model of normal aging. Ann. N.Y. Acad. Sci. 747, 382-406. doi: 10.1111/j.1749-6632.1994.tb44424.x

Dobrev, D., Milde, A. S., Andreas, K., and Ravens, U. (1999). The effects of verapamil and diltiazem on $\mathrm{N}-, \mathrm{P}$ - and Q-type calcium channels mediating dopamine release in rat striatum. Br. J. Pharmacol. 127, 576-582. doi: 10.1038/ sj.bjp.0702574

Dubovsky, S. L. (2018). Applications of calcium channel blockers in psychiatry: pharmacokinetic and pharmacodynamic aspects of treatment of bipolar disorder. Expert Opin. Drug Metab. Toxicol. 15, 35-47. doi: 10.1080/ 17425255.2019.1558206

Eikelenboom, P., Zhan, S. S., van Gool, W. A., and Allsop, D. (1994). Inflammatory mechanisms in Alzheimer's disease. Trends Pharmacol. Sci. 15, 447-450. doi: 10.1016/0165-6147(94)90057-4

Fleckenstein, A. (1977). Specific pharmacology of calcium in myocardium, cardiac pacemakers, and vascular smooth muscle. Ann. Rev. Pharmacol. Toxicol. 17, 149-166. doi: 10.1146/annurev.pa.17.040177.001053

Franco, R., and Petrovic, M. (2015). Suggesting a way to understand the actual potential of anti-Alzheimer's disease drugs that show promise in transgenic mouse models. Front. Neurol. 6, 206. doi: 10.3389/fneur.2015.00206

Freir, D. B., Costello, D. A., and Herron, C. A. (2003). A $\beta_{25-35}$-induced depression of long-term potentiation in area CA1 in vivo and in vitro is attenuated by verapamil. J. Neurophysiol. 89, 3061-3069. doi: 10.1152/jn.00992.2002

Frost, G. R., Jonas, L. A., and Li, Y.-M. (2019). Friend, foe or both? Immune activity in Alzheimer's disease. Front. Aging Neurosci. 11, 337. doi: 10.3389/ fnagi.2019.00337

Galzin, A. M., and Langer, S. Z. (1983). Presynaptic alpha 2-adrenoceptor antagonism by verapamil but not by diltiazem in rabbit hypothalamic slices. Br. J. Pharmacol. 78, 571-577. doi: 10.1111/j.1476-5381.1983.tb08817.x

García-Albea, E., Jiménez-Jiménez, F. J., Ayuso-Peralta, L., Cabrera-Valdivia, F., Vaquero, A., and Tejeiro, J. (1993). Parkinsonism unmasked by verapamil. Clin. Neuropharmacol. 16, 263-265. doi: 10.1097/00002826-199306000-00011

Ghosal, S., Bang, E., Yue, W., Hare, B. D., Lepack, A. E., Girgenti, M. J., et al. (2018). Activity-dependent BDNF release is required for the rapid antidepressant actions of scopolamine. Biol. Psychiatry 83, 29-37. doi: 10.1016/j.biopsych.2017.06.017

Giménez de Bejar, V., Caballero Bleda, M., Popović, N., and Popović, M. (2017). Verapamil blocks scopolamine enhancement effect on memory consolidation in passive avoidance task in rats. Front. Pharmacol. 8, 566. doi: 10.3389/ fphar.2017.00566

Green, A. R., DeSouza, R. J., Davies, E. M., and Cross, A. J. (1990). The effects of $\mathrm{Ca} 2+$ antagonists and hydralazine on central 5-hydroxytryptamine biochemistry and function in rats and mice. Br. J. Pharmacol. 99, 41-46. doi: 10.1111/j.1476-5381.1990.tb14651.x

Gupta, S. K., Atkinson, L., Tu, T., and Longstreth, J. A. (1995). Age and gender related changes in stereoselective pharmacokinetics and pharmacodynamics of 
verapamil and norverapamil. Br. J. Clin. Pharmacol. 40, 325-331. doi: 10.1111/ j.1365-2125.1995.tb04554.x

Hampel, H., Mesulam, M. M., Cuello, A. C., Farlow, M. R., Giacobini, E., Grossber, G. T., et al. (2018). The cholinergic system in the pathophysiology and treatment of Alzheimer's disease. Brain. 141, 1917-1933. doi: 10.1093/brain/awy132

Hashioka, S., Klegeris, A., and McGeer, P. L. (2012). Inhibition of human astrocyte and microglia neurotoxicity by calcium channel blockers. Neuropharmacology 63, 685-691. doi: 10.1016/j.neuropharm.2012.05.033

Henaka, M. T., Carson, M. J., El Khoury, J., Landreth, G. E., Brosseron, F., Feinstein, D. L., et al. (2015). Neuroinflammation in Alzheimer's disease. Lancet Neurol. 14, 388-405. doi: 10.1016/S1474-4422(15)70016-5

Hermida, R. C., Ayala, D. E., and Calvo, C. (2005). Administration-timedependent effects of antihypertensive treatment on the circadian pattern of blood pressure. Curr. Opin. Nephrol. Hypertens. 14, 453-459. doi: 10.1097/ 01.mnh.0000174144.07174.74

Hermida, R. C., Ayala, D. E., Calvo, C., Portaluppi, F., and Smolensky, M. H. (2007). Chronotherapy of hypertension: administration-time-dependent effects of treatment on the circadian pattern of blood pressure. Adv. Drug Deliv. Rev. 59, 923-939. doi: 10.1016/j.addr.2006.09.021

Hersi, M., Irvine, B., Gupta, P., Gomes, J., Birkett, N., and Krewski, D. (2017). Risk factors associated with the onset and progression of Alzheimer's disease: a systematic review of the evidence. Neurotoxicology 61, 143-187. doi: 10.1016/ j.neuro.2017.03.006

Ishibashi, H., Yatani, A., and Akaike, N. (1995). Block of P-type Ca2+ channels in freshly dissociated rat cerebellar Purkinje neurons by diltiazem and verapamil. Brain Res. 695, 88-91. doi: 10.1016/0006-8993(95)00815-8

Jespersen, C. M., Frederiksen, M., Hansen, J. F., Klitgaard, N. A., and Sørum, C. (1989). Circadian variation in the pharmacokinetics of verapamil. Eur. J. Clin. Pharmacol. 37, 613-615. doi: 10.1007/bf00562555

Khachaturian, Z. S. (1989). Calcium, membranes, aging, and Alzheimer's disease. Introduction and overview. Ann. N. Y. Acad. Sci. 568, 1-4. doi: 10.1111/j.17496632.1989.tb12485.x

Kim, S., and Rhim, H. (2011). Effects of Amyloid- $\beta$ peptides on voltage-gated Ltype Cav1.2 and Cav1.3 $\mathrm{Ca}^{2+}$ channels. Mol. Cells 32, 289-294. doi: 10.1007/ s10059-011-0075-x

Kim, S. H., Noh, M. Y., Kim, H. J., Oh, K. W., Park, J., Lee, S., et al. (2019). A therapeutic strategy for Alzheimer's disease focused on immune-inflammatory modulation. Dement. Neurocogn. Disord. 18, 33-46. doi: 10.12779/dnd.2019.18.2.33

Kivipelto, M., Helkala, E. L., Laakso, M. P., Hänninen, T., Hallikainen, M., Alhainen, K., et al. (2001). Midlife vascular risk factors and Alzheimer's disease in later life: longitudinal, population-based study. BMJ 322, 14471451. doi: $10.1136 / \mathrm{bmj} .322 .7300 .1447$

Krecic-Shepard, M. E., Barnas, C. R., Slimko, J., Jones, M. P., and Schwartz, J. B. (2000). Gender-specific effects on verapamil pharmacokinetics an7d pharmacodynamics in humans. J. Clin. Pharmacol. 40, 219-230. doi: $10.1177 / 00912700022008883$

Krikler, D. M., and Spurrell, R. A. J. (1974). Verapamil in the treatment of paroxysmal supraventicular tachycardia. Postgrad. Med. J. 50, 447-453. doi: 10.1136/pgmj.50.585.447

Kuhnke, D., Jedlitschky, G., Grube, M., Krohn, M., Jucker, M., Mosyagin, I., et al. (2007). MDR1-P-Glycoprotein (ABCB1) Mediates transport of Alzheimer's amyloid- $\beta$ peptides-implications for the mechanisms of $A \beta$ clearance at the blood-brain barrier. Brain Pathol. 17, 347-353. doi: 10.1111/j.17503639.2007.00075.x

Kumar, A., Ekavali,, Mishra, J., Chopra, K., and Dhull, D. K. (2016). Possible role of P-glycoprotein in the neuroprotective mechanism of berberine in intracerebroventricular streptozotocin-induced cognitive dysfunction. Psychopharmacol. (Berl). 233, 137-152. doi: 10.1007/s00213-015-4095-7

Kuryshev, Y. A., Brown, A. M., Duzic, E., and Kirsch, G. E. (2014). Evaluating state dependence and subtype selectivity of calcium channel modulators in automated electrophysiology assays. Assay Drug Dev. Technol. 12, 110-119. doi: 10.1089/adt.2013.552

Kwon, S. H., Lee, H. K., Kim, J. A., Hong, S. I., Kim, H. C., Jo, T. H., et al. (2010). Neuroprotective effects of chlorogenic acid on scopolamine-induced amnesia via antiacetylcholinesterase and anti-oxidative activities in mice. Eur. J. Pharmacol. 649, 210-217. doi: 10.1016/j.ejphar.2010.09.001

LaFerla, F. M. (2002). Calcium dyshomeostasis and intracellular signaling in Alzheimer's disease. Nat. Rev. Neurosci. 3, 862-872. doi: 10.1038/nrn960
Lam, F. C., Liu, R., Lu, P., Shapiro, A. B., Renoir, J., Sharom, F. J., et al. (2001). $\beta$ amyloid efflux mediated by p-glycoprotein. J. Neurochem. 76, 1121-1128. doi: 10.1046/j.1471-4159.2001.00113.x

Lam, J., Coleman, N., Garing, A. L. A., and Wulff, H. (2013). The therapeutic potential of small-conductance $\mathrm{KCa} 2$ channels in neurodegenerative and psychiatric diseases. Expert Opin. Ther. Targets 17, 1203-1220. doi: 10.1517/ 14728222.2013 .823161

Leone, M., Giustiniani, A., and Proietti Cecchini, A. (2017). Cluster headache: present and future therapy. Neurol. Sci. 38, S45-S50. doi: 10.1007/s10072-017-2924-7

Lewis, G. R. J., Morley, K. D., Lewis, B. M., and Bones, P. J. (1978). The treatment of hypertension with verapamil. N.Z. Med. J. 87, 351-354.

Li, Y., Sun, H., Chen, Z., Xu, H., Bu, G., and Zheng, H. (2016). Implications of GABAergic neurotransmission in Alzheimer's disease. Front. Aging Neurosci. 8, 31. doi: $10.3389 /$ fnagi.2016.00031

Liu, J., and Li, L. (2019). Targeting autophagy for the treatment of Alzheimer's disease: challenges and opportunities. Front. Mol. Neurosci. 12, 203. doi: 10.3389/fnmol.2019.00203

Liu, Y., Lo, Y. C., Qian, L., Crews, F. T., Wilson, B., Chen, H. L., et al. (2011). Verapamil protects dopaminergic neuron damage through a novel antiinflammatory mechanism by inhibition of microglial activation. Neuropharmacology 60, 373-380. doi: 10.1016/j.neuropharm.2010.10.002

Livesley, B., Catley, P. F., Campbell, R. C., and Oram, S. (1973). Double-blind evaluation of verapamil, propranolol and isosorbide dinitrate against placebo in the treatment of angina pectoris. Br. Med. J. 1, 375-378. doi: 10.1136/bmj.1.5850.375

Love, S., and Miners, J. S. (2016). Cerebrovascular disease in ageing and Alzheimer's disease. Acta Neuropathol. 131, 645-658. doi: 10.1007/s00401-015-1522-0

Luurtsema, G., Molthoff, C. F., Windhorst, A. D., Smit, J. W., Keizer, H., Boellaard, R., et al. (2003). (R)- and (S)-[ $\left.{ }^{11} \mathrm{C}\right]$ verapamil as PET-tracers for measuring Pglycoprotein function: in vitro and in vivo evaluation. Nucl. Med. Biol. 30, 747751. doi: 10.1016/s0969-8051(03)00078-7

Lyketsos, C. G., Carillo, M. C., Ryan, J. M., Khachaturian, A. S., Trzepacz, P., Amatniek, J., et al. (2011). Neuropsychiatric symptoms in Alzheimer's disease. Alzheimer's. Dement. 7, 532-539. doi: 10.1016/j.jalz.2011.05.2410

Matta, C., Zákány, R., and Mobasheri, A. (2015). Voltage-dependent calcium channels in chondrocytes: Roles in health and disease. Curr. Rheumatol. Rep. 17, 43. doi: 10.1007/s11926-015-0521-4

Maxwell, C. J., Hogan, D. B., and Ebly, E. M. (1999). Calcium-channel blockers and cognitive function in elderly people: results from the Canadian study of health and aging. CMAJ 161, 501-506. doi: 10.1136/bmj.319.7213.806b

McGeer, E. G., and McGeer, P. L. (2010). Neuroinflammation in Alzheimer's disease and mild cognitive impairment: a field in its infancy. J. Alzheimers Dis. 19, 355-361. doi: 10.3233/JAD-2010-1219

McGeer, P. L., Akiyama, H., Itagaki, S., and McGeer, E. G. (1989). Immune system response in Alzheimer's disease. Can. J. Neurol. Sci. 16, 516-527. doi: 10.1017/ s0317167100029863

McGrath, E. R., Beiser, A. S., DeCarli, C., Plourde, K. L., Vasan, R. S., Greenber, S. M., et al. (2017). Blood pressure from mid- to late life and risk of incident dementia. Neurology 89, 2447-2454. doi: 10.1212/WNL.0000000000004741

Melone, M. A. B., Dato, C., Paladino, S., Coppola, C., Trebini, C., Giordana, M. T., et al. (2018). Verapamil inhibits Ser202/Thr205 phosphorylation of tau by blocking TXNIP/ROS/p38 MAPK pathway. Pharm. Res. 35:44, 1-14. doi: 10.1007/s11095-017-2276-2

Meyer, J. S., and Hardenberg, J. (1983). Clinical effectiveness of calcium entry blockers in prophylactic treatment of migraine and cluster headaches. Headache. 23, 266-277. doi: 10.1111/j.1526-4610.1983.hed2306266.x

Midtbø, K., Hals, O., Lauve, O., van der Meer, J., and Storstein, L. (1986). Studies on verapamil in the treatment of essential hypertension: a review. Br. J. Clin. Pharamacol. 21 (Suppl. 2), 165S-171S. doi: 10.1111/j.1365-2125.1986.tb02867.x

Miyake, M. M., Nocera, A., and Miyake, M. M. (2018). P-glycoprotein and chronic rhinosinusitis. World J. Otorhinolaryngol. Head Neck Surg. 4, 169-174. doi: 10.1016/j.wjorl.2018.07.002

Murchison, D., McDermott, A. N., LaSarge, C. L., Peebles, K. A., Bizon, J. L., and Griffith, W. H. (2009). Enhanced calcium buffering in F344 rat cholinergic basal forebrain neurons is associated with age-related cognitive impairment. J. Neurophysiol. 102, 2194-2207. doi: 10.1152/jn.00301.2009

Nayler, W. G., and Dillon, J. S. (1986). Calcium antagonists and their mode of action: an historical overview. Br. J. Clin. Pharmac. 21, 97S-107S. doi: 10.1111/ j.1365-2125.1986.tb02859.x 
Nicita, F., Spalice, A., Raucci, U., Iannetti, P., and Parisi, P. (2016). The possible use of the L-type calcium channel antagonist verapamil in drug-resistant epilepsy. Expert Rev. Neurother. 16, 9-15. doi: 10.1586/14737175.2016.1121097

Nimmrich, V., and Eckert, A. (2013). Calcium channel blockers and dementia. Br. J. Pharmacol. 169, 1203-1210. doi: 10.1111/bph.12240

Nimmrich, V., Grimm, C., Draguhn, A., Barghorn, S., Lehmann, A., Schoemaker, H., et al. (2008). Amyloid $\beta$ oligomers ( $A \beta_{1-42}$ globulomer) suppress spontaneous synaptic activity by inhibition of P/Q-type calcium currents. J. Neurosci. 28, 788797. doi: 10.1523/JNEUROSCI.4771-07.2008

Noguchi, T., Leise, T. L., Kingsbury, N. J., Diemer, T., Wang, L. L., Henson, M. A., et al. (2017). Calcium circadian rhythmicity in the suprachiasmatic nucleus: cell autonomy and network modulation. eNeuro 4, 1-12. doi: 10.1523/ ENEURO.0160-17.2017

Pandareesh, M. D., and Anand, T. (2013). Neuromodulatory propensity of Bacopa monniera against scopolamine-induced cytotoxicity in PC12 cells via downregulation of AChE and up-regulation of BDNF and muscarnic-1 receptor expression. Cell Mol. Neurobiol. 33, 875-884. doi: 10.1007/s10571-013-9952-5

Park, H.-W., and Lee, J. H. (2014). Calcium channel blockers as potential therapeutics for obesity-associated autophagy defects and fatty liver pathologies. Autophagy 10, 2385-2386. doi: 10.4161/15548627.2014.984268

Parodi, O., Maseri, A., and Simonetti, I. (1979). Management of unstable angina at rest by verapamil. A double-blind crossover study in coronary care unit. $\mathrm{Br}$. Heart J. 41, 167-174. doi: 10.1136/hrt.41.2.167

Pasternak, B., Svanström, H., Nielsen, N. M., Fugger, L., Melbye, M., and Hviid, A. (2012). Use of calcium channel blockers and Parkinson's disease. Am. J. Epidemiol. 175, 627-635. doi: 10.1093/aje/kwr362

Pchitskaya, E., Popugaeva, E., and Bezprozvanny, I. (2018). Calcium signaling and molecular mechanisms underlying neurodegenerative diseases. Cell Calcium 70, 87-94. doi: 10.1016/j.ceca.2017.06.008

Peineau, S., Rabiant, K., Pierrefiche, O., and Potier, B. (2018). Synaptic plasticity modulation by circulating peptides and metaplasticity: involvement in Alzheimer's disease. Pharmacol. Res. 130, 385-401. doi: 10.1016/ j.phrs.2018.01.018

Petersen, A. S., Barloese, M. C. J., Snoer, A., Soerensen, A. M. S., and Jensen, R. H. (2019). Verapamil and cluster headache: Still a mystery. A narrative review of efficacy, mechanisms and perspectives. Headache 59, 1198-1211. doi: 10.1111/ head. 13603

Ponne, S., Kumar, C. R., and Boopathy, R. (2019). Verapamil attenuates scopolamine induced cognitive deficits by averting oxidative stress and mitochondrial injury- a potential agent for Alzheimer's disease. Metab. Brain Dis. 35, 503-515. doi: 10.1007/s11011-019-00498-x

Popova, J., Staneva-Stoytcheva, D., and Mutafova, V. (1990). Effects of the $\mathrm{Ca}^{+-}$ antagonists nifedipine, verapamil, flunarizine and of the calmodulin antagonist trifluoperazine on muscarinic cholinergic receptors in rat cerebral cortex. Gen. Pharmacol. 21, 317-319. doi: 10.1016/0306-3623(90)90830-f

Popova, J., Staneva-Stoytcheva, D., Ivanova, E., and Tosheva, T. (1991). The longterm treatment with the $\mathrm{Ca}^{2+-}$ antagonists nifedipine, verapamil, flunarizine and with the calmodulin antagonist trifluoperazine decreases the activity of 5$\mathrm{HT}_{1}$ receptors in rat cerebral cortex and hippocampus. Gen. Pharmacol. 22, 1147-1149. doi: 10.1016/0306-3623(91)90593-u

Popović, M., Popović, N., Jovanova-Nešić, K., Bokonjić, D., Dobrić, S., and Kostić V.S. and Rosić, N. (1997a). Effect of physostigmine and verapamil on active avoidance in an experimental model of Alzheimer's disease. Int. J. Neurosci. 90, 87-97. doi: 10.3109/00207459709000628

Popović, M., Popović, N., Jovanova-Nešić, K., Bokonjić, D., Dobrić, S., and Rosić, N. (1997b). Open field behavior in nucleus basalis magnocellularis-lesioned rats treated with physostigmine and verapamil. Int. J. Neurosci. 91, 181-188. doi: 10.3109/00207459708986375

Popović, M., Caballero-Bleda, M., Popović, N., Bokonjić, D., and Dobrić, S. (1997c). Neuroprotective effect of chronic verapamil treatment on cognitive and noncognitive deficits in an experimental Alzheimer's disease in rats. Int. J. Neurosci. 92, 87-97. doi: 10.3109/00207459708986392

Popović, M., Caballero-Bleda, M., Puelles, L., and Popović, N. (1998a). Importance of immunological and inflammatory processes in the pathogenesis and therapy of Alzheimer's disease. Int. J. Neurosci. 95, 203-236. doi: 10.3109/ 00207459809003341

Popović, M., Popović, N., Bokonjić, D., Dobrić, S., Ugrešić, N., and Kostić, V. S. (1998b). Effect of acute physostigmine and verapamil treatment on aggressive and depressive behavior in rats with lesioned nucleus basalis magnocellularis. Neurosci. Res. Commun. 23, 13-22. doi: 10.1002/s1520-6769(199807/08) 23:1<13::AID-NRC2>3.0.CO;2-O

Popović, M., Popović, N., Caballero-Bleda, M., and Puelles, L. (1998c). Effect of acute verapamil treatment on body temperatura in nucleus basalis magnocellularis-lesioned rats. Neurosci. Res. Commun. 23, 181-187. doi: 10.1002/(SICI)1520-6769(199811/12)23:3<181::AID-NRC6>3.0.CO;2-E

Popović, M., Popović, N., and Caballero-Bleda, M. (1999). Effect of acute verapamil treatment on cold restraint-induced gastric lesions in rats with lesioned nucleus basalis magnocellularis. Neurosci. Res. Commun. 25, 163-171. doi: 10.1002/(SICI)1520-6769(199911/12)25:3<163::AID-NRC5>3.0.CO;2-4

Popović, M., Caballero-Bleda, M., Popović, N., Puelles, L., van Groen, T., and Witter, M. P. (2006). Verapamil prevents, in a dose-dependent way, the loss of ChAT-immunoreactive neurons in the cerebral cortex following lesions of the rat nucleus basalis magnocellularis. Exp. Brain Res. 170, 368-375. doi: 10.1007/ s00221-005-0219-3

Qiu, C., von Strauss, E., Winbland, B., and Fratiglioni, L. (2004). Decline in blood pressure over time and risk of dementia. A longitudinal study from the Kungsholmen project. Stroke 35, 1810-1815. doi: 10.1161/01.STR.0000133128.42462.ef

Ramsden, M., Henderson, Z., and Pearson, H. A. (2002). Modulation of Ca2+ channel currents in primary cultures of rat cortical neurones by amyloid beta protein (1-40) is dependent on solubility status. Brain Res. 956, 254-261. doi: 10.1016/s0006-8993(02)03547-3

Rayasam, G. V., and Balganesh, T. S. (2015). Exploring the potential of adjunct therapy in tuberculosis. Trends Pharmcol. Sci. 36, 506-513. doi: 10.1016/j.tips.2015.05.005

Rice, R. A., Berchtodl, N. C., Cotman, C. W., and Green, K. N. (2014). Age-related downregulation of the CaV3.1 T-type calcium channel as a mediator of amyloid beta production. Neurobiol. Aging 35, 1002-1011. doi: 10.1016/ j.neurobiolaging.2013.10.090

Rinne, J., Paljärvi, L., and Rinne, U. K. (1987). Neuronal size and density in the nucleus basalis of Meynert in Alzheimer's disesase. J. Neurol. Sci. 79, 67-76. doi: 10.1016/0022-510X(87)90260-7

Russo, G. I., Milenkovic, U., Hellstrom, W., Levine, L. A., Ralph, D., and Albersen, M. (2018). Clinical efficacy of injection and mechanical therapy for Peyronie's disease: a systematic review of the literature. Eur. Urol. 74, 767-781. doi: 10.1016/j.eururo.2018.07.005

Saari, G. N., Scott, W. C., and Brooks, B. W. (2017). Global scanning assessment of calcium channel blockers in the environment: Review and analysis of occurrence, ecotoxicology and hazards in aquatic systems. Chemosphere 189, 466-478. doi: 10.1016/j.chemosphere.2017.09.058

Sasaki, M., Tateishi, T., and Ebihara, A. (1993). The effects of age and gender on the stereoselective pharmacokinetics of verapamil. Clin. Pharmacol. Ther. 54, 278.285. doi: 10.1038/clpt.1993.148

Schamroth, L., Krikler, D. M., and Garrett, C. (1972). Immediate effects of intravenous verapamil in cardiac arrhythmias. Br. Med. J. 1, 660-664. doi: $10.1136 / \mathrm{bmj} .1 .5801 .660$

Schwartz, J. B., Troconiz, I. F., Verotta, D., Liu, S., and Capili, H. (1993). Aging effects on stereoselective pharmacokinetics and pharmacodynamics of verapamil. J. Pharmacol. Exp. Ther. 265, 690-698.

Schwartz, J. B., Capili, H., and Daugherty, J. (1994). Aging of women alters Sverapamil pharmacokinetics and pharmacodynamics. Clin. Pharmacol. Ther. 55, 509-517. doi: 10.1038/clpt.1994.64

Schwartz, J. B. (1990). Aging alters verapamil elimination and dynamics: single dose and steady-state responses. J. Pharmacol. Exp. Ther. 255, 364-373.

Schwartz, J. B. (1996). Calcium antagonists in the elderly. A risk-benefit analysis. Drugs Aging 9, 24-36. doi: 10.2165/00002512-199609010-00003

Sekhar, D. S., Shwetha, B. K., Haimavathi, B., and Vikram, P. (2016). The effect of calcium channel blockers against scopolamine induced cognitive impairment and oxidative stress. Int. J. Basic Clin. Pharmacol. 5, 2199-2211. doi: 10.18203/ 2319-2003.ijbcp20163262

Sen, A. P., Boksa, P., and Quirion, R. (1993). Brain calcium channel related dihydropyridine and phenylalkylamine binding sites in Alzheimer's, Parkinson's and Huntington's diseases. Brain Res. 611, 216-221. doi: 10.1016/0006-8993(93)90505-H

Shad, K. F., and Saeed, S. A. (2007). The metabolism of serotonin in neuronal cells in culture and platelets. Exp. Brain Res. 183, 411-416. doi: 10.1007/s00221-007-1133-7

Silei, V., Fabrizi, C., Venturini, G., Salmona, M., Bugiani, O., Tagliavini, F., et al. (1999). Activation of microglial cells by PrP and beta-amyloid fragments raises 
intracellular calcium through L-type voltage sensitive calcium channels. Brain Res. 818, 168-170. doi: 10.1016/S0006-8993(98)01272-4

Silverberg, G. D., Messier, A. A., Miller, M. C., Machan, J. T., Majmudar, S. S., Stopa, E. G., et al. (2010). Amyloid efflux transporter expression at the bloodbrain barrier declines in normal aging. J. Neuropathol. Exp. Neurol. 69, 10341043. doi: 10.1097/NEN.0b013e3181f46e25

Šimić, G., Babić Leko, M., Wray, S., Harrington, C., Delalle, I., Jovanov-Milošević, N., et al. (2017). Monoaminergic neuropathology in Alzheimer's disease. Prog. Neurobiol. 151, 101-138. doi: 10.1016/j.pneurobio.2016.04.001

Sitges, M., and Guarneros, A. (1998). Chronic verapamil modifies striatal and frontal cortex dopamine levels. Eur. Neuropsychopharmacol. 8, 105-111. doi: 10.1016/s0924-977x(97)00053-9

Skoog, I., Lernfelt, B., Landahl, S., Palmertz, B., Andreasson, L. A., Nilsson, L., et al. (1996). 15-year longitudinal study of blood pressure and dementia. Lancet 347, 1141-1145. doi: 10.1016/s0140-6736(96)90608-x

Song, L., and $\mathrm{Wu}, \mathrm{X}$. (2016). Development of efflux pump inhibitors in antituberculosis therapy. Int. J. Antimicrob. Agents. 47, 421-429. doi: 10.1016/ j.ijantimicag.2016.04.007

Staneva-Stoytcheva, D., Popova, J., Mutafova-Yambolieva, V., and Alov, P. (1990). Influence of long-term treatment with the $\mathrm{Ca} 2(+)$-antagonists nifedipine, verapamil, flunarizine and with the calmodulin antagonist trifluoperazine on beta-adrenoceptors in rat cerebral cortex. Gen. Pharmacol. 21, 149-152. doi: 10.1016/0306-3623(90)90611-o

Staneva-Stoytcheva, D., Danchev, N., and Popov, P. (1991). Changes in benzodiazepine receptors of rat brain after long-term treatment with the $\mathrm{Ca} 2+$-antagonists nifedipine, verapamil, flunarizine and with the calmodulin antagonist trifluoperazine. Gen. Pharmacol. 22, 1151-1154. doi: 10.1016/03063623(91)90594-V

Staneva-Stoytcheva, D., Danchev, N., and Popov, P. (1992). Long-term treatment with different calcium- and calmodulin-antagonists induces changes in rat brain alpha-adrenoceptors. Gen. Pharmacol. 23, 61-63. doi: 10.1016/03063623(92)90048-o

Tönnies, E., and Trushina, E. (2017). Oxidative stress, synaptic dysfunction and Alzheimer's disease. J. Alzheimers Dis. 57, 1105-1121. doi: 10.3233/JAD-161088

Tao, L., Liang, M., Wenjun, H., Rui, Z., Miaoling, L., Yan, Y., et al. (2013). The effects of verapamil on SK2 channel in myocardium cells from human chronic atrial fibrillation. Heart 99, A28. doi: 10.1136/heartjnl-2013-303992.086

Tarabova, B., Lacinova, L., and Engel, J. (2007). Effects of phyenilalkylamines and benzothiazepines on Cav1.3-mediated Ca2+ currents in neonatal mouse inner hair cells. Eur. J. Pharmacol. 573, 39-48. doi: 10.1016/j.ejphar.2007.06.050

Taylor, J. E., and Defeudis, F. V. (1984). Inhibition of [3H]spiperone binding to 5HT2 receptors of rat cerebral cortex by the calcium antagonists verapamil and D600. Eur. J. Pharmacol. 106, 215-216. doi: 10.1016/0014-2999(84)90703-9

Tfelt-Hansen, P., and Tfelt-Hansen, J. (2009). Verapamil for cluster headache. Clinical pharmacology and possible mode of action. Headache 49, 117-125. doi: $10.1111 /$ j.1526-4610.2008.01298.x

Thibault, O., Gant, J. C., and Landfield, P. W. (2007). Expansion of the calcium hypothesis of brain aging and Alzheimer's disease: minding the store. Aging Cell 6, 307-317. doi: 10.1111/j.1474-9726.2007.00295.x

Turner, A. L., and Perry, M. S. (2017). Outside the box: Medications worth considering when traditional antiepileptic drugs have failed. Seizure 50, 173185. doi: 10.1016/j.seizure.2017.06.022

van Assema, D. M. E., Lubberink, M., Boellaard, R., Schuit, R. C., Windhorst, A. D., Scheltens, P., et al. (2012a). P-glycoprotein function at the blood-brain barrier: Effects of age and gender. Mol. Imaging Biol. 14, 771-776. doi: 10.1007/s11307012-0556-0 van Assema, D. M. E., Lubberink, M., Boellaard, R., Schuit, R. C., Windhorst, A. D., Scheltens, P., et al. (2012b). Reproducibility of quantitative (R)- $\left[{ }^{11} \mathrm{C}\right]$ verapamil studies. EJNMMI Res. 2, 1. doi: 10.1186/2191-219X-2-1

Verhiel, S., Piatkowski de Grzymala, A., and van der Hulst, R. (2015). Mechanism of action, efficacy, and adverse events of calcium antagonists in hypertrophic scars and keloids: a systematic review. Dermatol. Surg 41, 1343-1350. doi: 10.1097/DSS.0000000000000506

Vogelgesang, S., Cascorbi, I., Schroeder, E., Pahnke, J., Kroemer, H. K., Siegmund, W., et al. (2002). Deposition of Alzheimer's $\beta$-amyloid is inversely correlated with P-glycoprotein expression in the brains of elderly non-demented humans. Pharmacogenetics 12, 535-541. doi: 10.1097/00008571-200210000-00005

Vogelgesang, S., Warzok, R. W., Cascorbi, I., Kunert-Keil, C., Schroeder, E., Kroemer, H. K., et al. (2004). The role of P-glycoprotein in cerebral amyloid angiopathy; implications for the early pathogenesis of Alzheimer's disease. Curr. Alzheimer Res. 1, 121-125. doi: 10.2174/1567205043332225

Wang, X., and Zheng, W. (2019). $\mathrm{Ca}^{2+}$ homeostasis dysregulation in Alzheimer's disease: a focus on plasma membrane and cell organelles. FASEB J. 33, 66976712. doi: 10.1096/fj.201801751R

Whitehouse, P. J., Price, A. W., Clark, A. W., Coyle, J. T., and Delong, M. R. (1981). Alzheimer's disease: evidence for selective loss of cholinergic neurons in the nucleus basalis. Ann. Neurol. 10, 122-126. doi: 10.1002/ana.410100203

Whitson, J. S., and Appel, S. H. (1995). Neurotoxicity of A $\beta$ amyloid protein in vitro is not altered by calcium channel blockade. Neurobiol. Aging 16, 5-10. doi: 10.1016/0197-4580(95)80002-9

Wisner, K. L., Peindl, K. S., Perel, J. M., Hanusa, B. H., Piontek, C. M., and Baab, S. (2002). Verapamil treatment for women with bipolar disorder. Biol. Psychiatry 51, 745-752. doi: 10.1016/s0006-3223(01)01338-5

Wu, Y.-E., Enoki, R., Oda, Y., Huang, Z.-L., Honma, K.-I., and Honma, S. (2018). Ultradian calcium rhythms in the paraventricular nucleus and subparaventricular zone in the hypothalamus. PNAS 115, E9469-E9478. doi: 10.1073/pnas.1804300115

Xiao, J., Li, S., Sui, Y., Wu, Q., Li, X., Xie, B., et al. (2014). Lactobacillus casei-01 facilitates the ameliorative effects of proanthocyanidins extracted from lotus seedpod on learning and memory impairment in scopolamine-induced amnesia mice. PloS One 9, e112773. doi: 10.1371/journal.pone.0112773

Yaser, S., Corrada, M., Brookmeyer, R., and Kawas, C. (2005). Calcium channel blockers and risk of AD: The Baltimore longitudinal study of aging. Neurobiol. Aging 26, 157-163. doi: 10.1016/j.neurobiolaging.2004.03.009

Yin, T., Kuo, S. C., Chang, Y. Y., Chen, Y. T., and Wang, K. K. (2017). Verapamil use is associated with reduction of newly diagnosed diabetes mellitus. J. Clin. Endocrinol. Metab. 102, 2604-2610. doi: 10.1210/jc.2016-3778

Yu, H., Li, M., Shen, X., Lv, D., Sun, X., Wang, J., et al. (2018). The requirement of Ltype voltage-dependent calcium channel (L-VDCC) in the rapid-acting antidepressant-like effects of scopolamine in mice. Int. J. Neuropsychopharmacol. 21, 175-186. doi: 10.1093/ijnp/pyx080

Conflict of Interest: The authors declare that the research was conducted in the absence of any commercial or financial relationships that could be construed as a potential conflict of interest.

Copyright (c) 2020 Popović, Morales-Delgado, Vidal Mena, Alonso, Pascual Martinez, Caballero Bleda and Popović. This is an open-access article distributed under the terms of the Creative Commons Attribution License (CC BY). The use, distribution or reproduction in other forums is permitted, provided the original author(s) and the copyright owner(s) are credited and that the original publication in this journal is cited, in accordance with accepted academic practice. No use, distribution or reproduction is permitted which does not comply with these terms. 